\title{
MODEL FOR PREDICTING FORMATION OF BLOWOUT ON COASTAL SAND DUNE USING CELLULAR AUTOMATON METHOD
}

\author{
Takuya Yokota ${ }^{1}$, Akio Kobayashi', Takaaki Uda ${ }^{2}$, Masumi Serizawa ${ }^{3}$, Atsunari Katsuki ${ }^{4}$ and \\ Yasuhito Noshi ${ }^{1}$
}

\begin{abstract}
On a sand dune, a blowout is often formed owing to wind effect. The formation of a blowout was observed on November 25, 2016 at the Node coast facing the Pacific Ocean, where a blowout has been formed to leave a concave topography. Then, a model for predicting the formation of a blowout was developed using a cellular automaton method, in which two important factors of saltation and avalanche were taken into account. The results of the numerical simulation were compared with the measured results on the Node coast, and the predicted and measured shapes of the blowout were in good agreement. Also, it was found that the direction of the beach access must be extended in the direction normal to the direction of prevailing wind to prevent blowout formation.
\end{abstract}

Keywords: sand dune; blowout; cellular automaton method; Node coast; Ishikari-hama Beach; field observation

\section{INTRODUCTION}

On a coast composed of fine sand, windblown sand could be deposited to form a coastal sand dune along the shoreline. Such a sand dune is not only an effective barrier against the inundation of sea water into the land in occasions of storm waves or tsunamis but also very important area in the protection of coastal environment, because the seaward marginal line of the sand dune covered with vegetation is often adopted as a hatching area for the loggerhead turtle Caretta caretta. In such a coastal dune, part of sand dune may be eroded by the effect of wind as a natural agent, resulting in the formation of a blowout. In other case, when a beach access across the sand dune from the land to the shoreline is artificially produced, the same phenomena that occur at the blowout naturally formed by the action of wind can be observed. Once a blowout is formed, the function of the sand dune as a coastal dike will be lost because the elevation of the sand dune locally decreases around the blowout. It is important, therefore, to investigate the formative process of a blowout and to develop a model for predicting the formation of a blowout on the sand dune from the engineering point of view. However, the studies on the formative mechanism of a blowout and the predictive model are rare, although there are many studies on windblown sand itself in the previous studies. In this study, the formation of a blowout on the coastal sand dune was investigated by field observations, and a model for predicting the formation of a blowout was developed using a cellular automaton method on the basis of field observations at the Node coast facing the Pacific Ocean and Ishikari-hama Beach in Hokkaido, Japan. Part of this paper was reported in Yokota et al. (2017), but further numerical simulation was carried out in this study.

\section{FIELD OBSERVATION OF BLOWOUT ON SAND DUNE AT NODE COAST}

\section{General Conditions of Study Area}

The formation of a blowout was investigated on a sand dune at the Node coast facing the Pacific Ocean in Chiba Prefecture, as shown in Fig. 1. On this coast, artificial headland No. 9 has been constructed together with headland No. 10 at a location $1.2 \mathrm{~km}$ south of headland No. 9 as a measure against beach erosion, and a sand dune area extends alongshore between the shoreline and the coastal residential area. In area A of the rectangular area in Fig. 1, a blowout has been formed, and the sand dune is truncated by this blowout (Fig. 2). Sand was transported inland across the sand dune, and was deposited at the landward end of this blowout while forming a steep slope with the angle of repose of sand (Fig. 3). On the other hand, coastal vegetation such as Carex kobomugi covers the seaward slope of the sand dune, including the top of the sand dune, as shown in Fig. 4. This coverage of the sand dune by coastal vegetation is effective in reducing the windblown sand. Similarly, coastal vegetation densely covers the landward slope of the sand dune except the blowouts, because there is few impact owing to salinity and windblown sand (Fig. 5), and it contrasts well with the exposed sand surface in the blowout area. In this study, topographic survey around this blowout was carried out on November 25, 2016, and the changes

\footnotetext{
${ }^{1}$ Department of Oceanic Architecture \& Engineering, College of Science \& Technology, Nihon University, 7-24-1

Narashinodai, Funabashi, Chiba 274-8501, Japan

${ }^{2}$ Public Works Research Center, 1-6-4 Taito, Tokyo 110-0016, Japan

${ }^{3}$ Coastal Engineering Laboratory Co., Ltd., 1-22-301 Wakaba, Shinjuku, Tokyo 160-0011, Japan

${ }^{4}$ College of Science \& Technology, Nihon University, 7-24-1 Narashinodai, Funabashi, Chiba 274-8501, Japan
} 

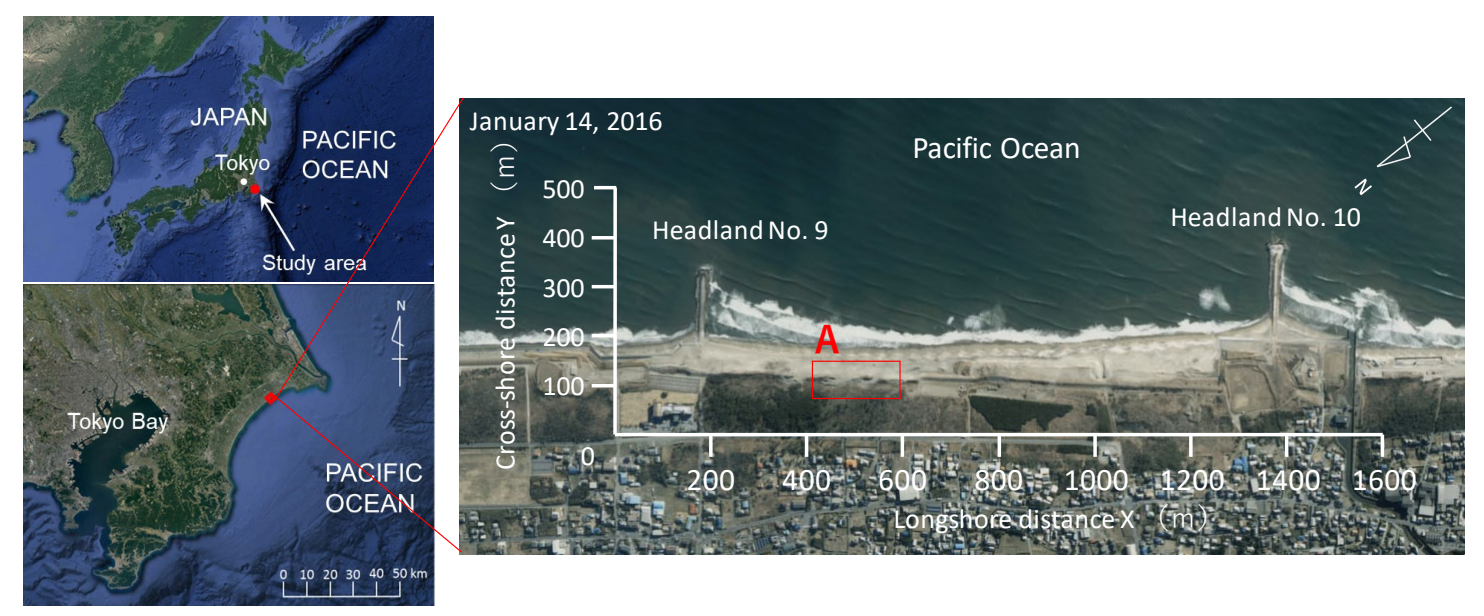

Figure 1. Aerial photograph of Node coast and study area of blowout on sand dune.

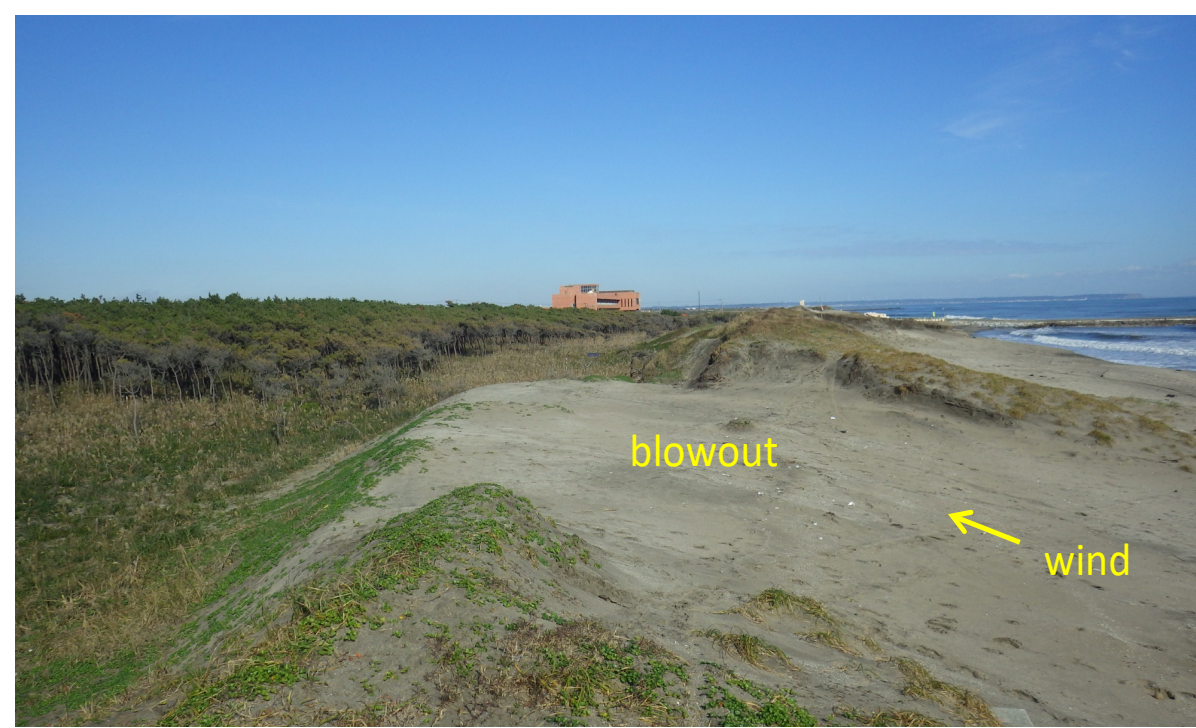

Figure 2. Blowout formation on sand dune on Node coast (November 25, 2016).

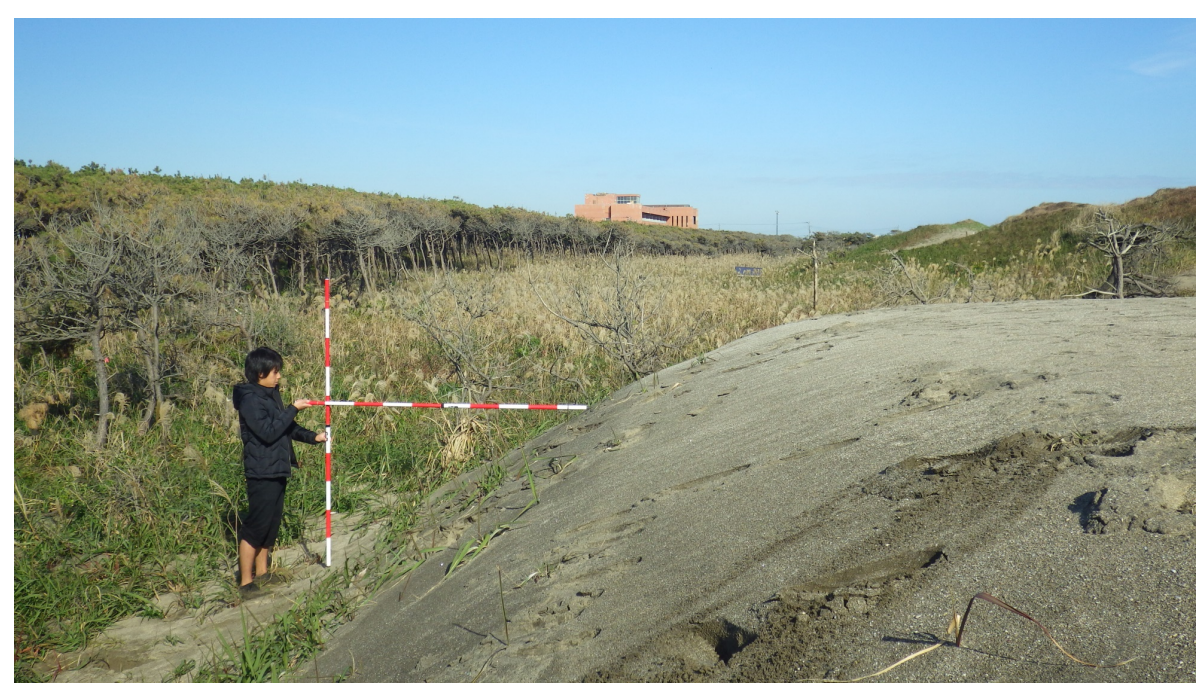

Figure 3. Steep slope of angle of repose of sand at landward end of blowout (November 25, 2016). 


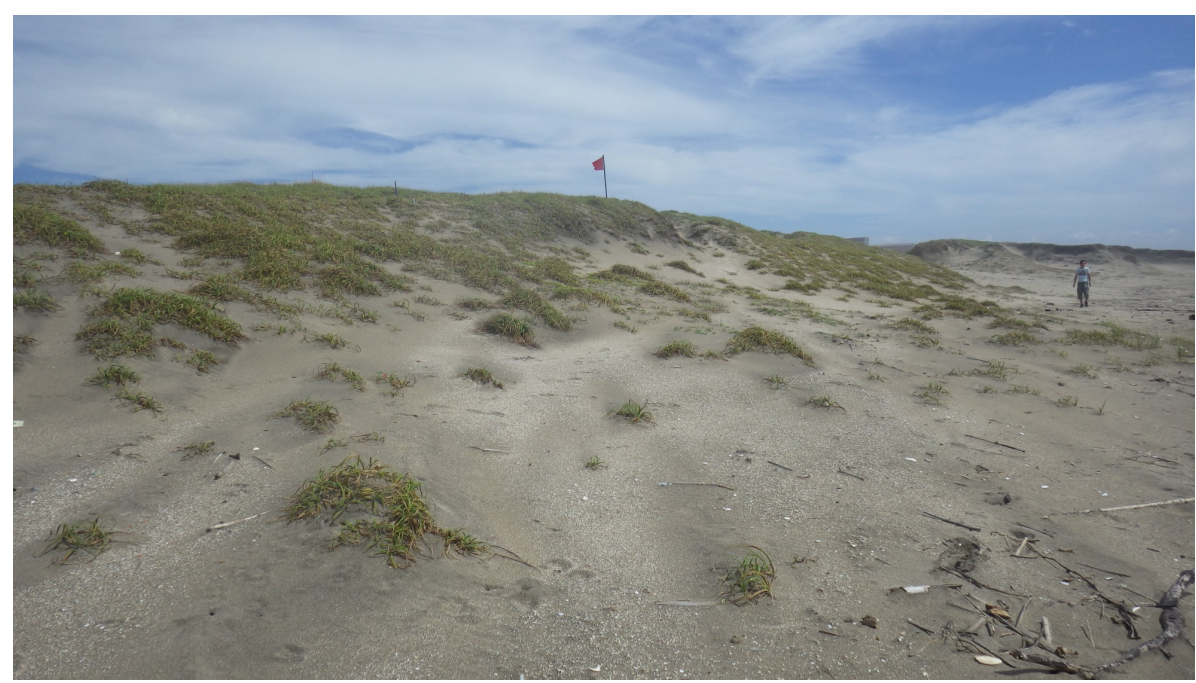

Figure 4. Coastal vegetation covering seaward slope of sand dune (November 25, 2016).

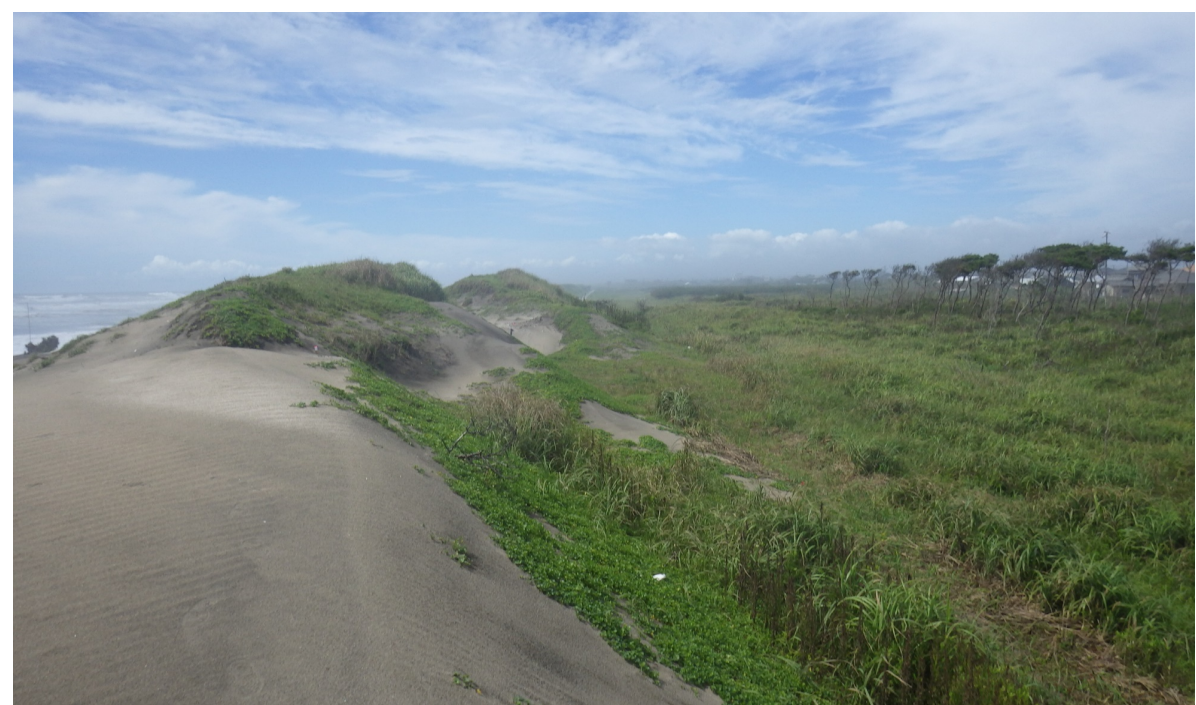

Figure 5. Vegetation densely covering landward slope of sand dune (November 25, 2016).

in the seaward marginal line of the sand dune and the shoreline of this coast were investigated using aerial photographs taken between 2012 and 2016. Furthermore, wind rose at the Yokoshiba-hikari observatory of Meteorological Agency was referred to investigate the occurrence of wind in this area.

\section{Results of Field Observation}

Figures 6(a) and 6(b) show the changes in the seaward marginal line of the sand dune and the shoreline on the Node coast, and an enlarged figure of the rectangular area in Fig. 6(a). It is found from Fig. 6 that several blowouts have gradually developed on the sand dune over time. In particular, the development of a blowout is significant between $X=300$ and $700 \mathrm{~m}$, and the seaward marginal line of the sand dune have become irregular, complicated shape, while the shoreline maintained almost the same position with variation over time. Figure 7 also shows the overall changes in the shoreline and the seaward marginal line of the sand dune in the entire period between 2012 and 2016. The irregularity of the seaward marginal line of sand dune increased with time because of the formation of a blowout, whereas the shoreline rotated clockwise during this period.

To investigate the development of a blowout on the sand dune, the data set of wave rose measured at the Yokoshiba-hikari observatory since 2012 were examined. Since the direction normal to the shoreline in the study area is approximately equal to the $\mathrm{SE}\left(\mathrm{N} 135^{\circ} \mathrm{E}\right)$, as shown in Fig. 1, and the shoreline runs in the direction of the NE-SW, the northerly wind does not contribute to the development of sand dune via landward transport of windblown sand from the shoreline. Therefore, wind rose between 2012 and 2015 was drawn as in Fig. 8, except the northerly wind out of the measured data. In this area, 
(a) 2012 vs 2013

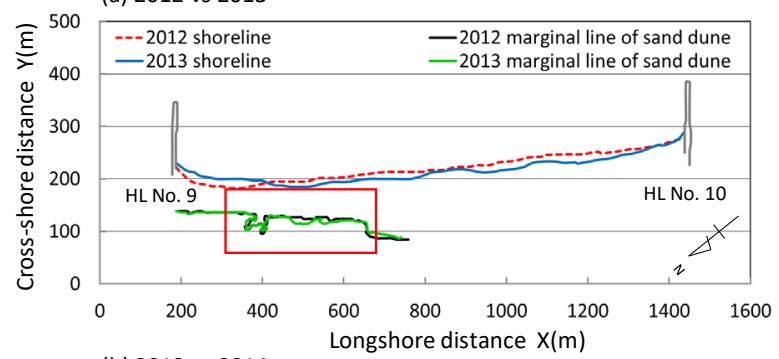

(b) 2013 vs 2014

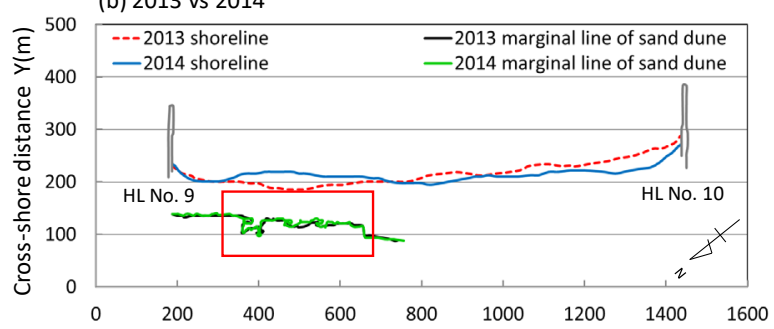

(c) 2014 vs 2015

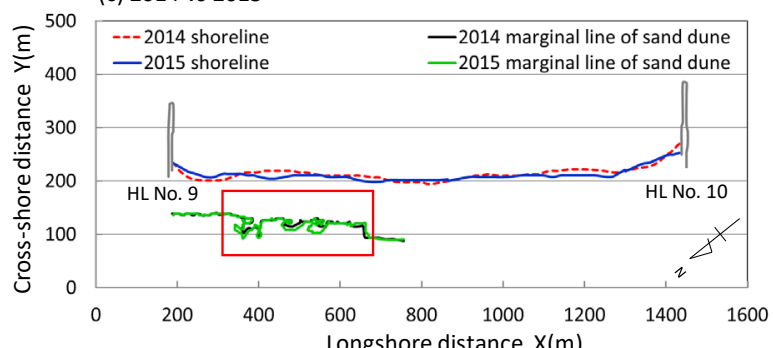

(d) 2015 vs 2016

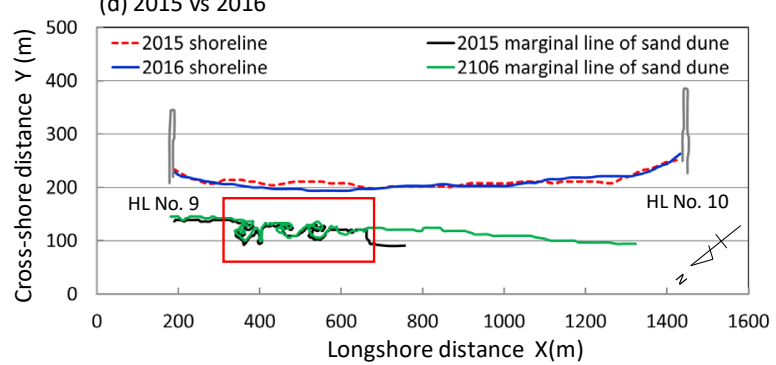

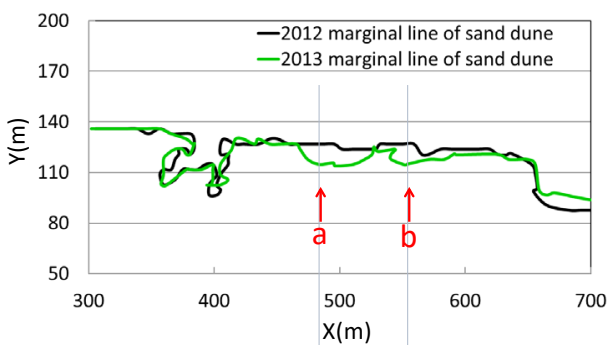
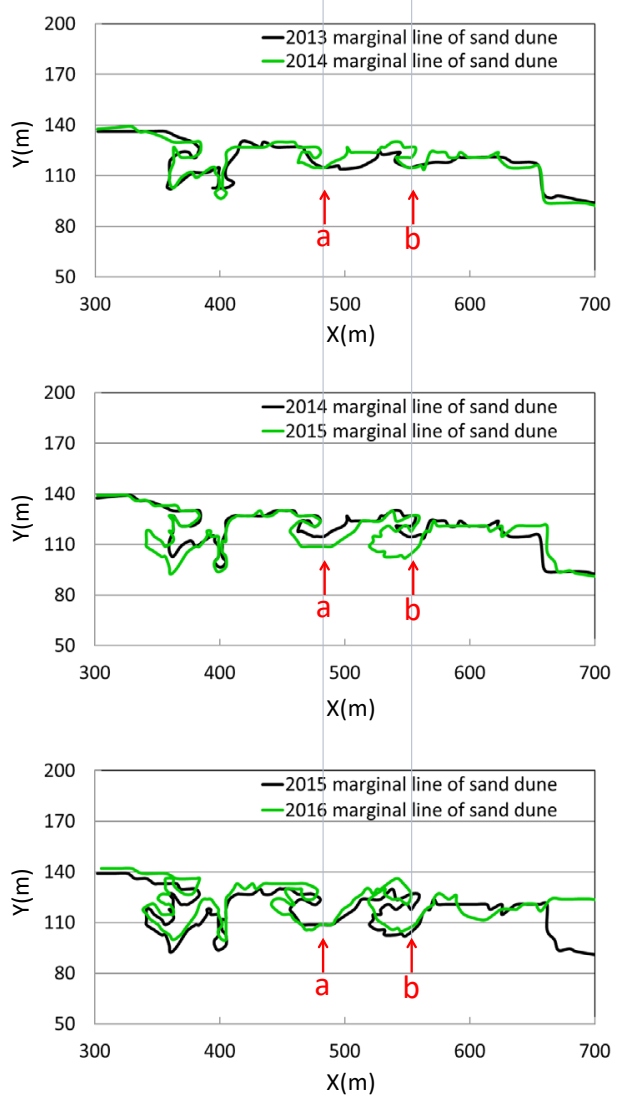

Figure 6. Changes in shoreline position and marginal line of sand dune in study area.

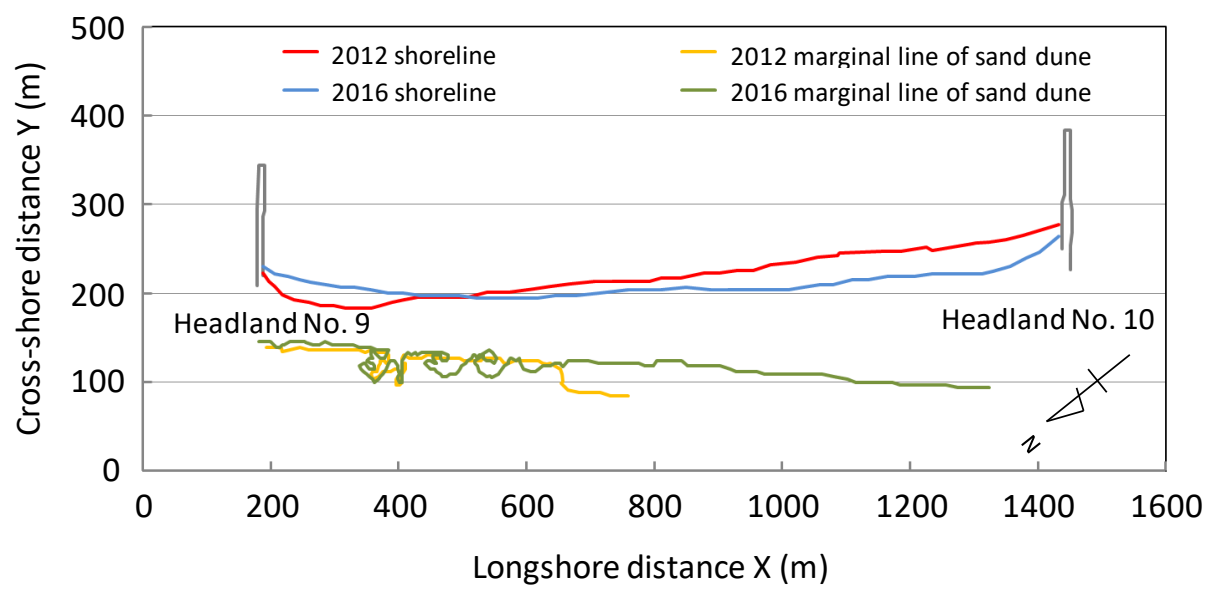

Figure 7. Changes in shoreline position and marginal line of sand dune between 2012 and 2016. 

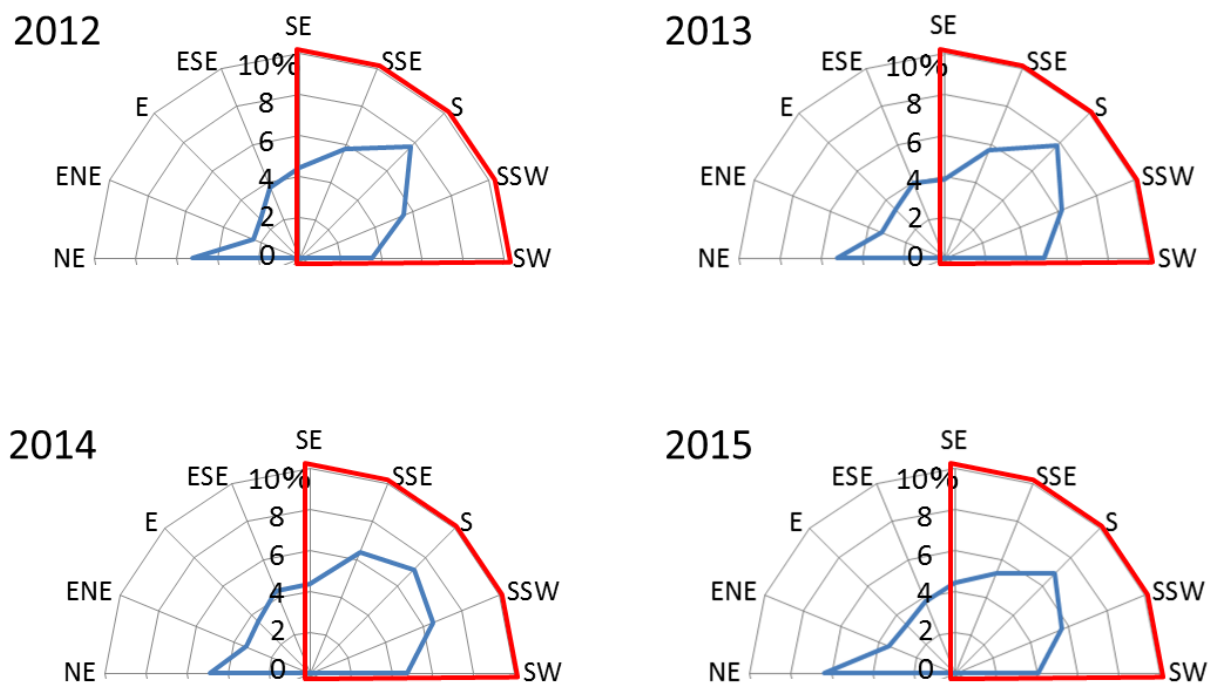

Figure 8. Probability distribution in wind direction between 2012 and 2015.

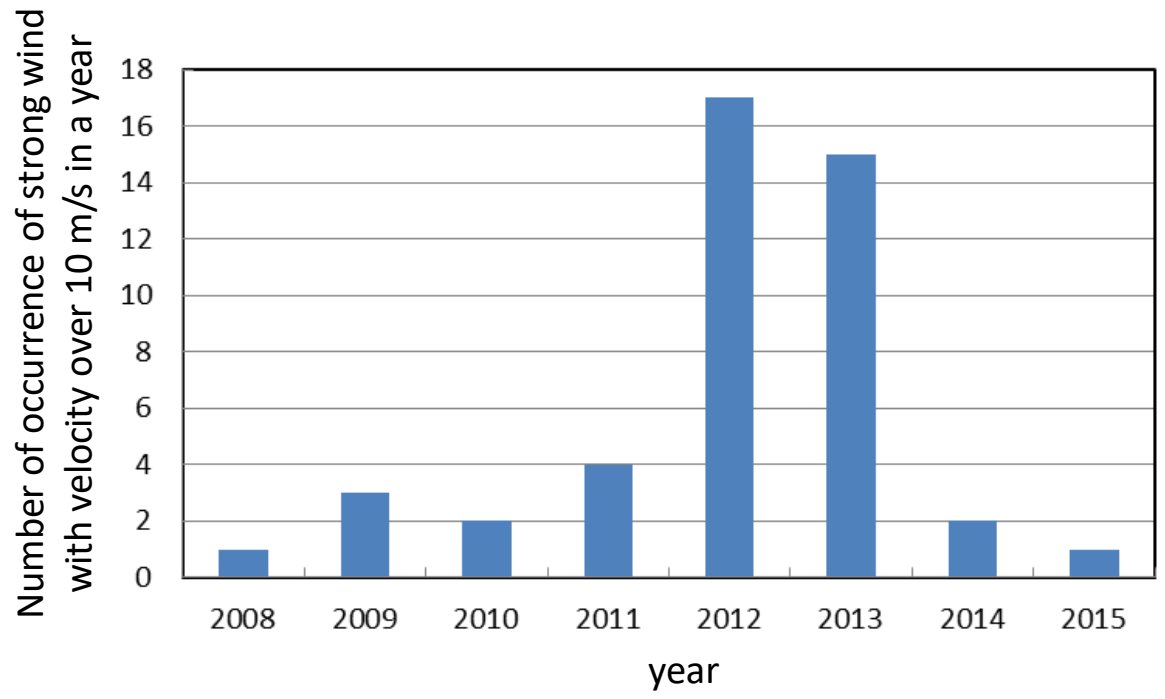

Figure 9. Number of occurrence of strong wind with wind velocity over $10 \mathrm{~m} / \mathrm{s}$.

the prevailing wind blows from the $\mathrm{S}$ at an oblique angle of $45^{\circ}$ relative to the direction normal to the mean shoreline.

The probability of occurrence of strong wind with a velocity over $10 \mathrm{~m} / \mathrm{s}$ from the $\mathrm{S}$ is shown in Fig. 9. The number of occurrence of strong wind with a velocity over $10 \mathrm{~m} / \mathrm{s}$ markedly increased in 2012 compared with that between 2008 and 2011, and this corresponds well to the fact that the blowout significantly developed since 2012 . Thus, the rapid development of a blowout, as shown by arrows a and b in Fig. 6, is considered to be due to the marked increase in the probability of occurrence of strong wind since 2012. Figure 10 shows the measured topography of the blowout formed at the location shown by arrow a in Fig. 6 on the sand dune. The concave contours were formed on the seaward slope of the blowout, whereas a steep slope was formed at the landward end of the blowout owing to windblown sand. Furthermore, a slender mound was formed in the extension of the south slope of the blowout, whereas the undercut steep slope was formed on the north slope.

\section{FIELD OBSERVATION OF SAND DUNE ON ISHIKARI-HAMA BEACH}

On the Node coast, a blowout has been naturally formed on the sand dune by wind, whereas on Ishikari-hama Beach in Ishikari City in Hokkaido, topographic changes were observed around a beach access extending from the inland to the shoreline. This situation was investigated on November 3, 2016. Figure 11 shows the satellite image of the bathing area of Ishikari-hama Beach. This bathing area has a 


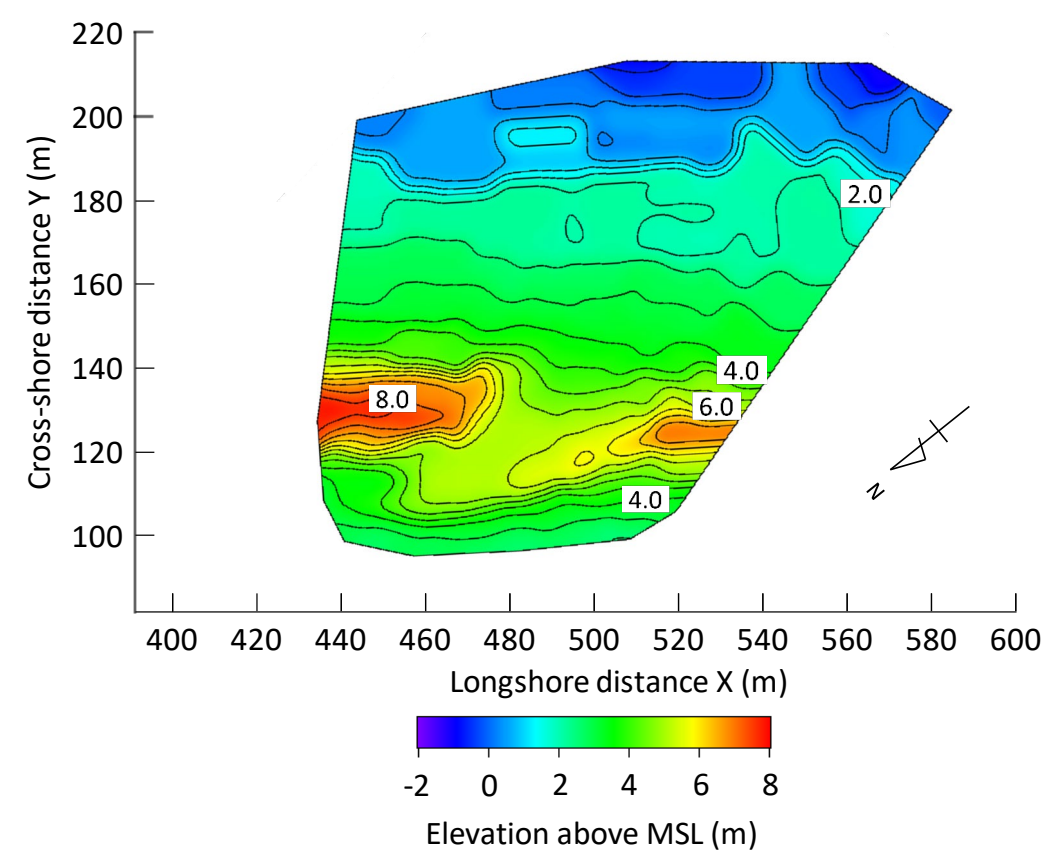

Figure 10. Topography around blowout measured on sand dune on Node coast.
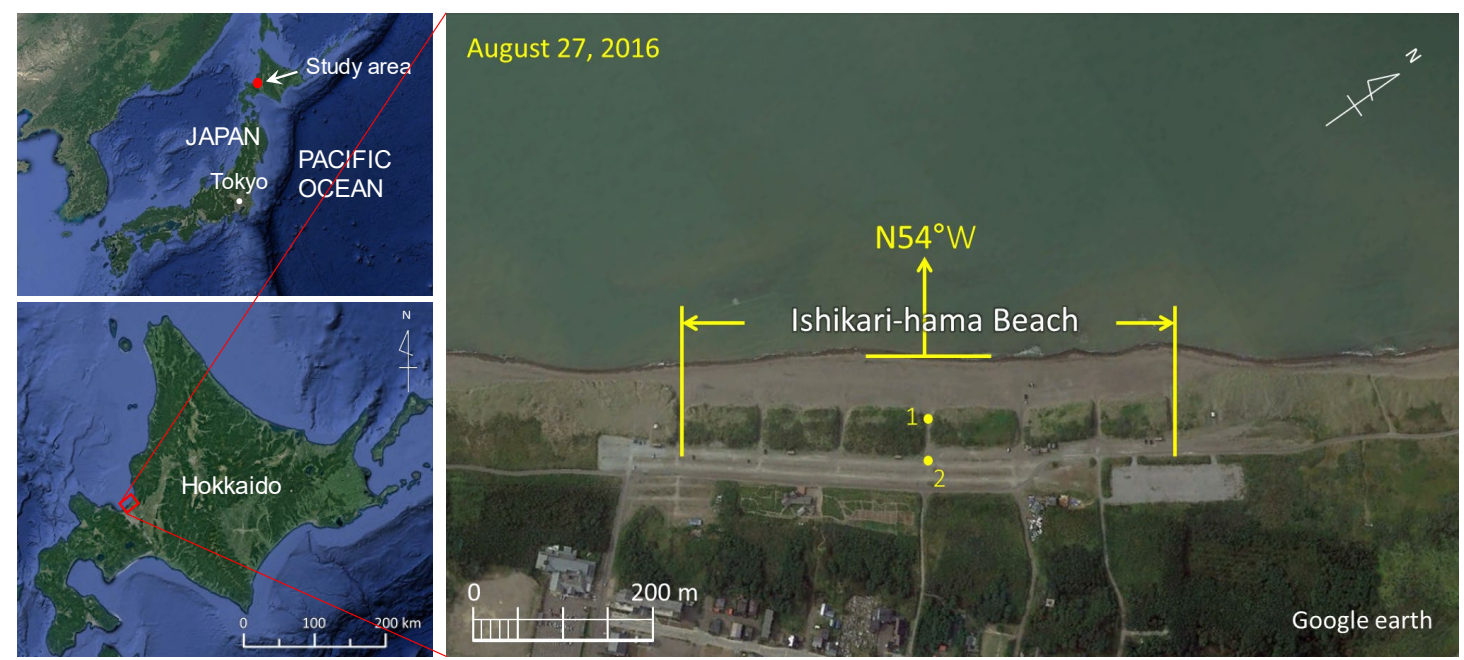

Figure 11. Satellite image of Ishikari-hama Beach facing Ishikari Bay.

longshore length of $550 \mathrm{~m}$ and $40 \mathrm{~m}$ width, and a sand dune of $5 \mathrm{~m}$ height and $50 \mathrm{~m}$ width separates the beach and a parking lot. The beach access from the parking lot to the shoreline extends at seven locations at $90 \mathrm{~m}$ intervals alongshore.

At St. 1 located in the central beach access, a large amount of windblown sand was transported from the beach to the parking lot, as shown in Fig. 12. In this case, the ground elevation on the right (north) side of the beach access was lower than that on the left (south) side, and the roots of the coastal vegetation were exposed as well, whereas a mound was formed on the left side because of deposition of windblown sand. In contrast, a large amount of sand was deposited on the right (north) side of the entrance of the beach access at St. 2 (Fig. 13). These facts suggest that the slope on the right (north) side of the beach access was severely eroded by wind as the undercut slope, which is subject to direct action by wind blowing from the direction counterclockwise with respect to the direction of the beach access, whereas on the left (south) slope of the beach access sand was deposited because of weaker wind velocity. Furthermore, at the entrance of the beach access, a large amount of sand was assumed to be deposited on the right (north) side. These observation results are in good agreement with that observed at the blowout on the Node coast, as shown in Fig. 10. 


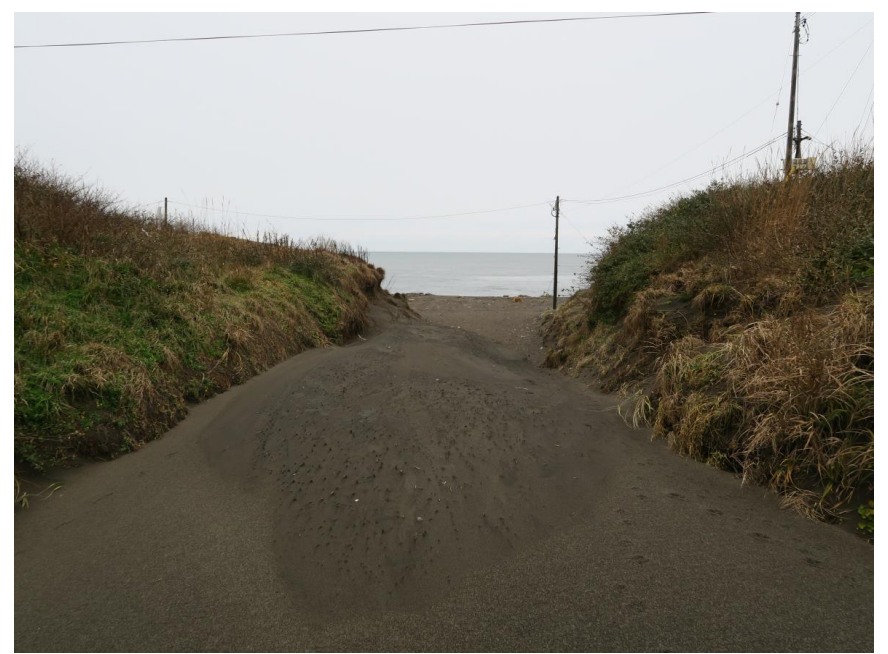

Figure 12. Sand deposition at landward entrance to coast (November 3, 2016).

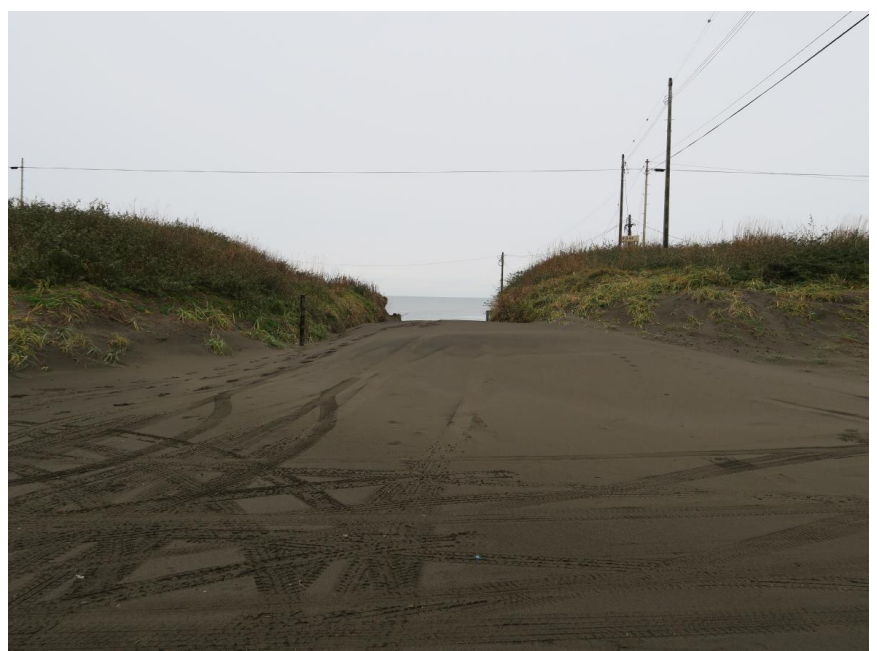

Figure 13. Sand deposition around entrance of beach access (November 3, 2016).

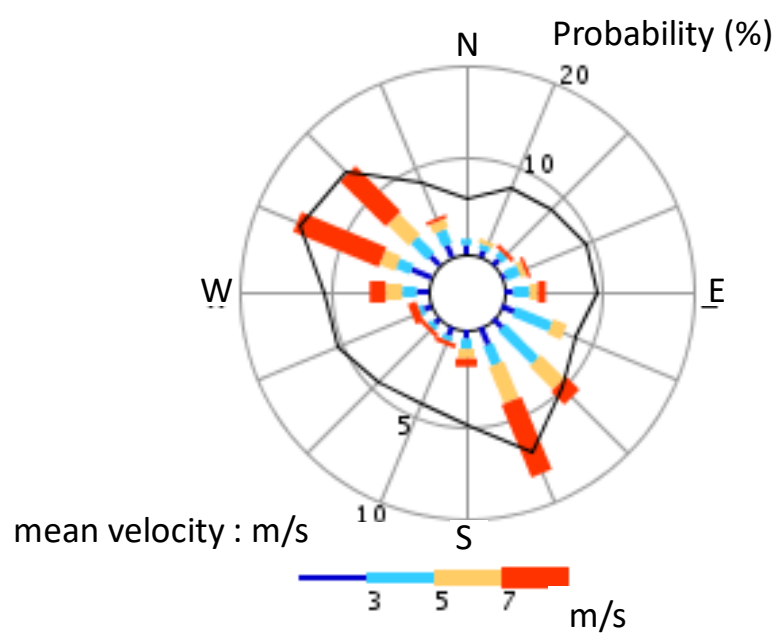

Figure 14. Wind rose at Ishikari-hama Beach (NEDO).

The direction normal to the mean shoreline in this area is $\mathrm{N} 54^{\circ} \mathrm{W}$, as shown in Fig. 11, and the beach access extends parallel to this direction. Asymmetric topographic changes along the beach access were assumed to occur, because the predominant wind blows obliquely with respect to the direction of the beach access. Figure 14 shows the wind rose in this area, referring to the local wind rose map produced 
by NEDO. The predominant wind direction in this area is WNW $\left(\mathrm{N} 67.5^{\circ} \mathrm{W}\right)$, and $\mathrm{NW}\left(\mathrm{N} 45^{\circ} \mathrm{W}\right)$ follows this. Most predominant direction of strong wind with the velocity over $7 \mathrm{~m} / \mathrm{s}$ is the WNW. Since the direction of the beach access is perpendicular to the shoreline, i.e., $\mathrm{N} 54^{\circ} \mathrm{W}$, wind from the WNW makes at $13.5^{\circ}$ counterclockwise relative to the direction of the beach access. Because of the predominance of the WNW wind in this area, the marked effect by wind from the WNW is considered to be left behind in the beach access, and thus the topographic features around the beach access as mentioned above can be explained. The relationship between the direction of a beach access crossing the sand dune and the predominant wind direction is a key factor to determine the impact of a blowout to the sand dune.

\section{MODEL FOR PREDICTING BLOWOUT FORMATION USING CELLULAR AUTOMATON METHOD}

\section{Predictive Model}

A model for predicting the formation of a blowout on the sand dune was developed referring a numerical model for predicting the formation of a sand dune by Katsuki and Kikuchi (2006) on the basis of the field observation on the Node coast. First, the two-dimentional meshes were taken on the Cartesian coordinate $(x, y)$, and the elevation at mesh point is set $h(x, y, t)$. Assume that the mesh size is sufficiently large compared with the size of the sand particle.

In this study, two most important processes of the saltation and avalanche were taken into account in the formation of a blowout on the sand dune together with the reduction effect of wind-blown sand owing to the coverage of the sand dune by vegetation. The saltation is a process that sand particle is transported by the action of wind, and the saltation distance $L_{\mathrm{s}}$ was assumed to be defined by Eq. (1).

$$
L_{\mathrm{s}}=\mathrm{a}+\mathrm{bh}(x, y, t)-\mathrm{ch}^{2}(x, y, t)
$$

Here, we set $\mathrm{a}=1.0, \mathrm{~b}=2.0$, and $\mathrm{c}=0.01$ in this study. Eq. (1) shows that the higher the elevation where sand particle is deposited, the longer distance the sand particle is transported by wind, but the saltation distance has a limit, as illustrated in Fig. 15. Eq. (1) is the simplest polynominal expression which can evaluate the observed results of the sand flux on a sand dune including multiphase flow (Andreotti et al. 2002), and the sand flux after the maximum value is regarded as a constant, and the value of Eq. (1) was evaluated only within the domain of increasing function, because Eq. (1) has a quadratic form in which a maximum value appears at an elevation, and $L_{\mathrm{S}}$ decreases in the elevation higher than the elevation where a maximum $L_{\mathrm{s}}$ occurs. Furthermore, taking into account of the observation facts that saltation does not occur downwind slope of the sand dune because a vortex is formed owing to the separation of the flow (Pye and Tsoar 1990), saltation is assumed to only occur on the upwind slope of the sand dune. Originally, the sand flux is given by the product of the moving mass and the saltation distance, and therefore the sand flux can be expressed by Eq. (1) when the wind velocity is a constant, assuming that the moving mass is a constant. When the wind velocity changes, the coefficient of Eq. (1) can be changed in response to the wind velocity (Katsuki et al. 2011). As a result, the relationship between the wind velocity and the formation of a sand dune can be well explained by Eq. (1). The moving mass $q$ was set to 0.01 . In the blowout, the moving mass should be locally increased, since sand movement is considered

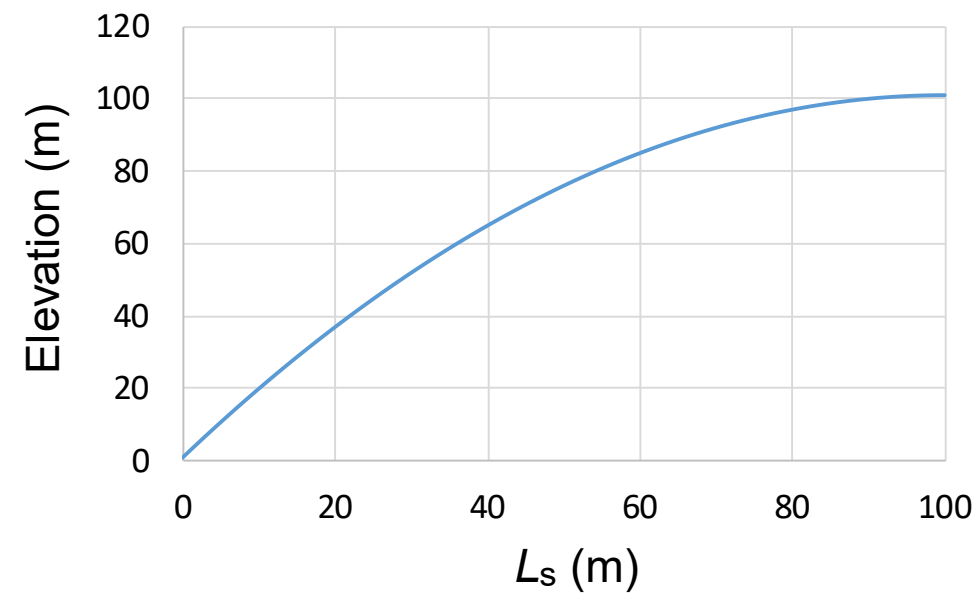

Figure 15. Relationship between saltation distance $L_{\mathrm{s}}$ and the elevation. 
to become active with the increase in wind velocity. However, because there is no general expression to evaluate the increase in the wind velocity in the blowout, the moving mass in the blowout was assumed to be $10 q$ in this study. In the cell model, the space has a nondimensional form, and the elevation $h$ can be normalyzed using the mean grain size of sand.

Consider that the sand particle moves from a point of $(x, y)$ to another point of $\left(x+L_{\mathrm{sx}}, y+L_{\mathrm{sy}}\right)$ at each time step, as shown in Fig. 16. Another process of sand movement of sand particle is the avalanche, which is a process that sand particle moves down the most steep slope when the slope is larger than that of the slope of angle of repose until the slope becomes smaller than the angle of repose slope (Fig. 17). In this study, the slope of angle of repose of sand particle was assumed to be $34^{\circ}$. Regarding the sand movement at a mesh point on the front surface of the sand dune, the slope is calculated from the difference in the elevation at a mesh point and another mesh point immediately upwind of the point, and sand particle is moved to the upwind direction, so that the slope is smaller than the assumed slope (Fig. 18). Here, the front slope of the sand dune was assumed to be $11^{\circ}$ and the backshore slope was $6.5^{\circ}$ on the basis of the measured slopes on the Node coast.

In the numerical simulation, the sand particle is first moved by the saltation, and the sand particle is moved corresponding to the slope in front, and finally sand movement by the avalanche takes place. Sand movement by the difference in the slope in front and real slope, and that by the avalanche are recurrently carried out until the stable topography is obtained. After a stable topography is obtained, the sand movement by the saltation is assumed to occur. In the calculation, saltation is assumed to be possible in

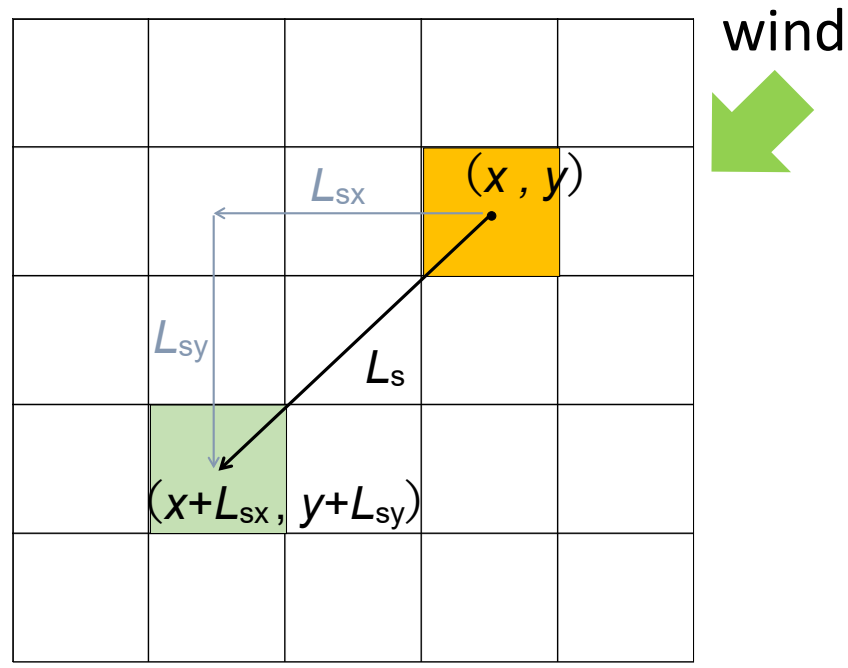

Figure 16. Schematic diagram of saltation process.

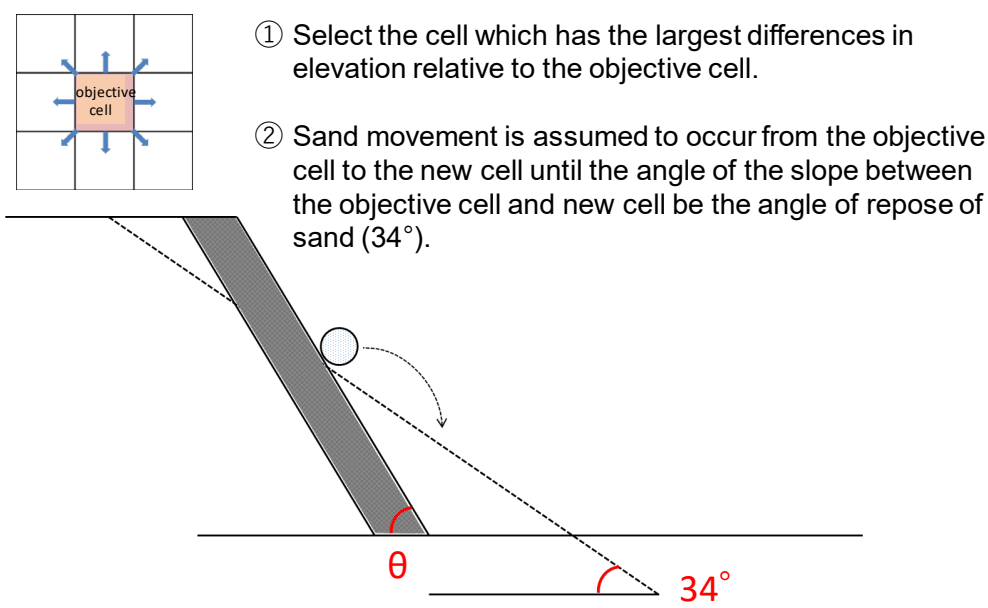

Figure 17. Schematic diagram of avalanche process. 


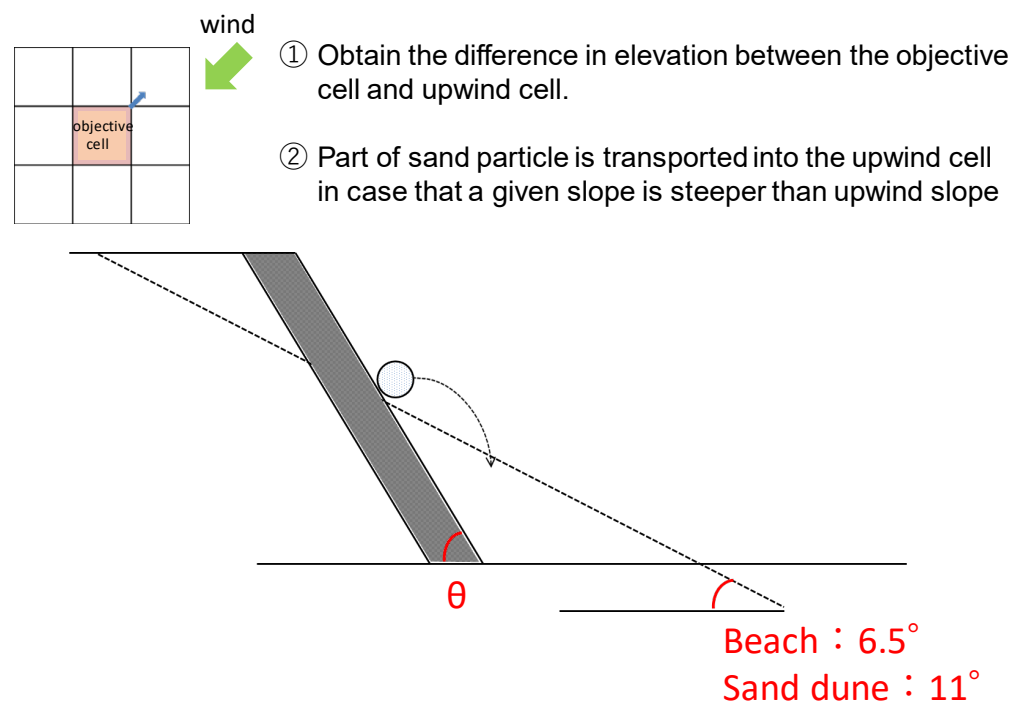

Figure 18. Schematic diagram showing formation of foreshore slope.

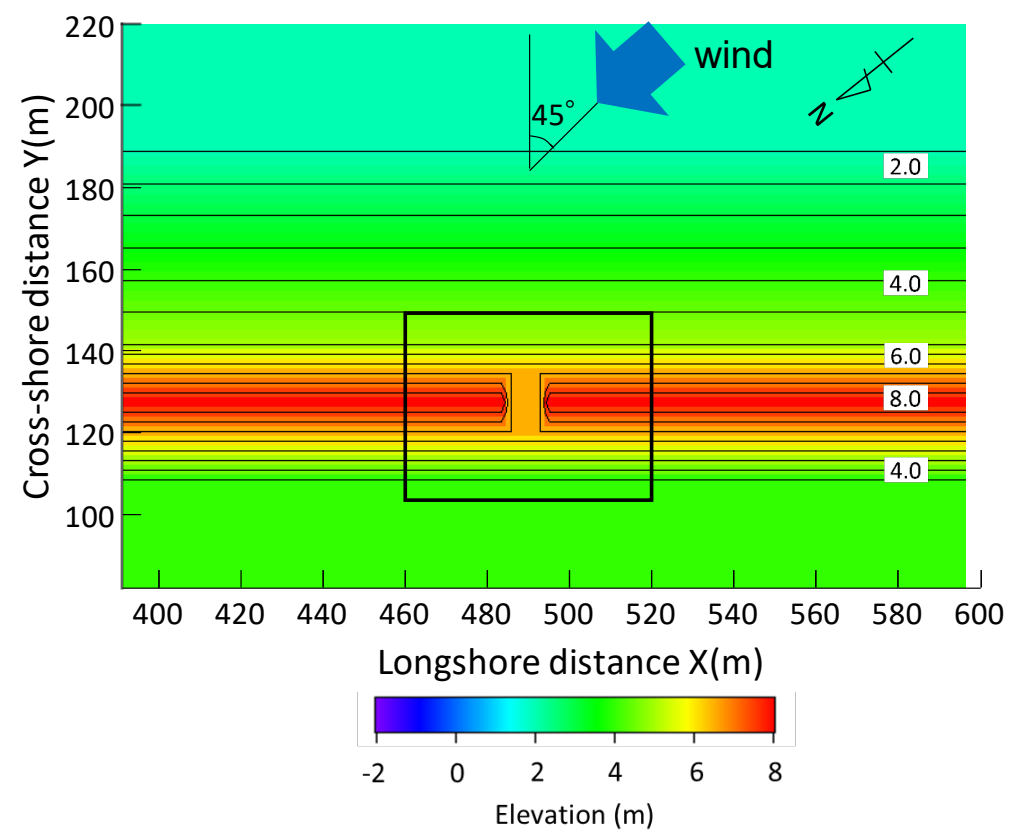

Figure 19. Initial topography and arrangement of beach access of $10 \mathrm{~m}$.

the direction of wind at the small gap with low elevation artificially produced on a part of the slope of the sand dune, and saltation is incapable because of the coverage by vegetation in the other area including the sand dune and the hinterland.

\section{Results of Calculation}

Figure 19 shows the initial topography of the sand dune, and the arrangement of a beach access (a narrow gap) to reach the shoreline across the sand dune as a typical case, assuming that wind obliquely blows at an angle of $45^{\circ}$ relative to the direction normal to the sand dune. Furthermore, we assumed that a narrow gap was formed owing to the anthropogenic factors, such as walking on the sand dune, resulting that coastal vegetation is withered by walking on the sand dune. In reality, the width and the direction of the beach access to the shoreline may vary from place to place, so that the direction of the beach access was altered in three cases in the calculation; normal to the sand dune crest, and at an angle of $\pm 45^{\circ}$ to the direction normal to the sand dune crest, as shown in Fig. 20, while changing the width of the beach access as 1,5 , and $10 \mathrm{~m}$. Thus, the effect of the change in width and direction of the beach access to the formation of a blowout was studied in nine cases (Types a-i). 
(a)

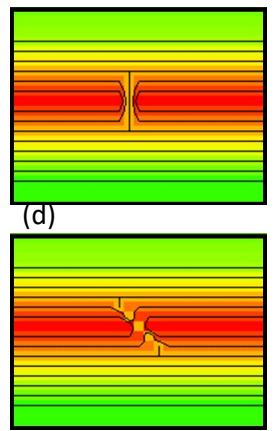

(g)

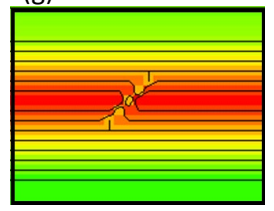

(b)

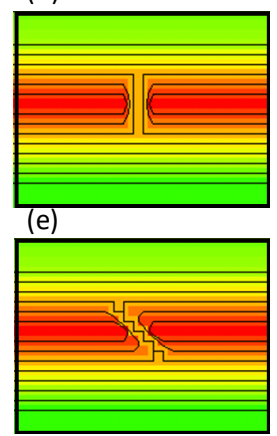

(h)

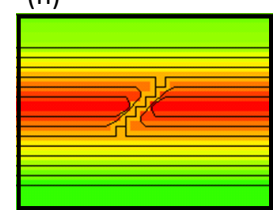

(c)
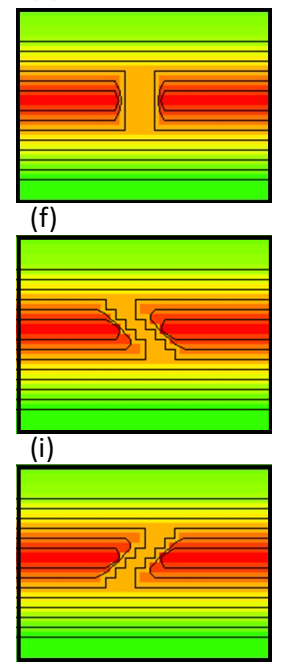

Figure 20. Nine types of beach access across sand dune.

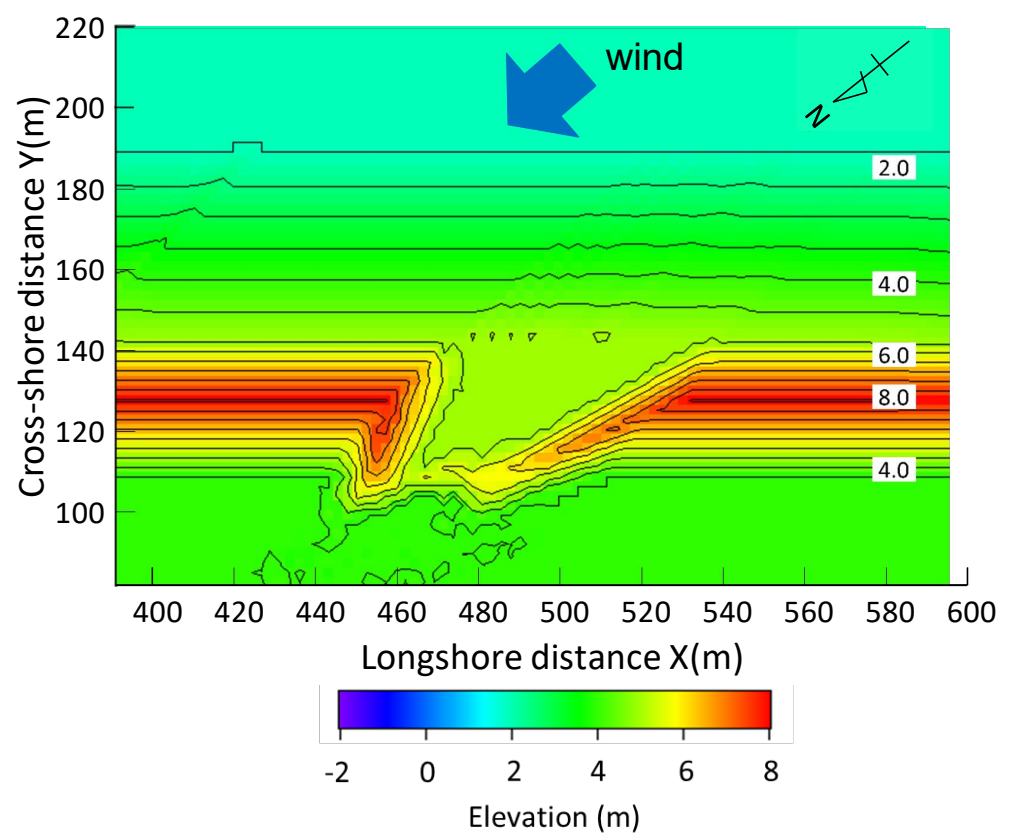

Figure 21. Calculation result of formation of blowout in Type c.

Figure 21 shows the calculation result of the formation of a blowout after 800 steps in Type $\mathrm{c}$ with the beach access of $10 \mathrm{~m}$ width. Because wind from the south blows to the hinterland through a narrow gap, a blowout was rapidly formed. A steep slope was formed along the north slope of the beach access, which is the undercut slope against the south wind, whereas a slender mound was formed in the extension of the south slope. Windblown sand was deposited behind the sand dune, while forming a steep slope with the angle of repose of sand. These characteristics well explain the results shown in Fig. 10 and the observation results at Ishikari-hama Beach.

The change in the direction of the beach access causes significant change in the formation of a blowout. While maintaining the width of the beach access to be $5 \mathrm{~m}$, the calculation was carried out when the direction of the beach access was altered. The results of calculation after 800 steps of Types b, e, and $\mathrm{h}$ are shown in Fig. 22. A blowout was formed in Type $\mathrm{b}$ with a beach access extending in the direction normal to the sand dune and Type $\mathrm{h}$ extending in the same direction of wind, whereas no blowout was formed in Type e, and the beach access was maintained as it was, preventing windblown sand from invading the hinterland. It is concluded that the direction of the beach access is better to be extended in the direction normal to the direction of prevailing wind to prevent blowout formation. 


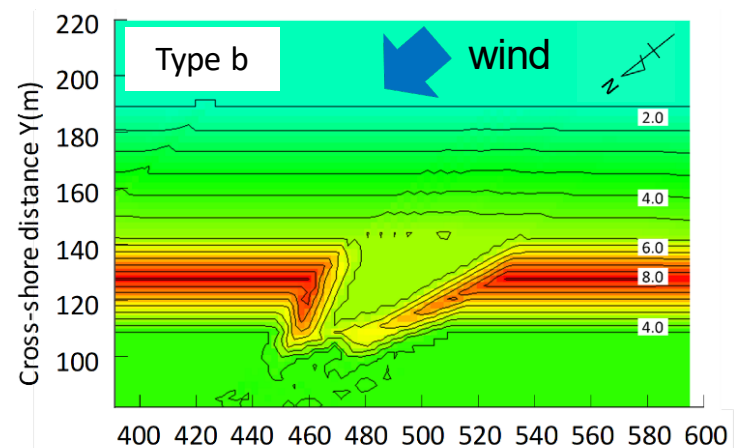

Longshore distance $X(\mathrm{~m})$

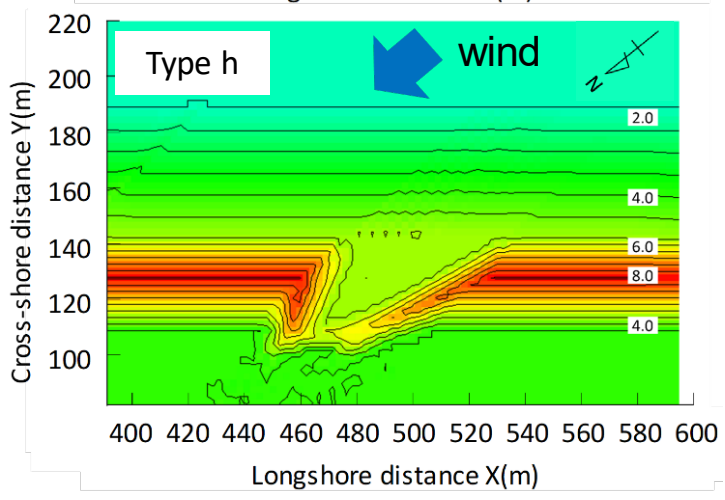

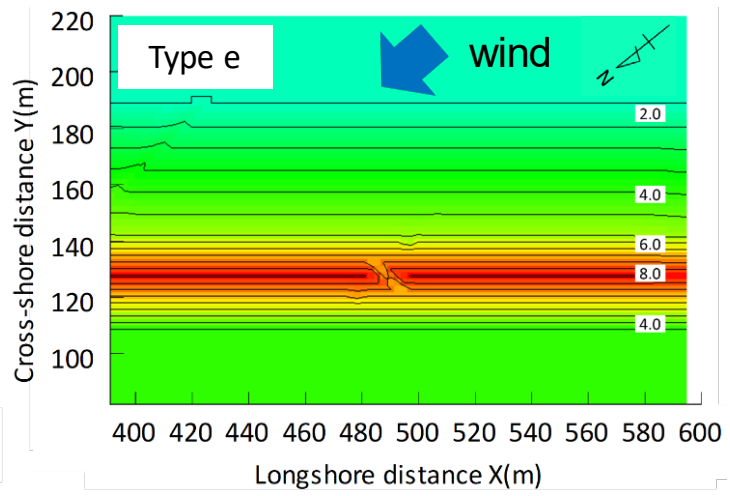

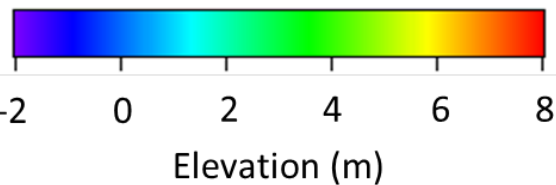

Figure 22. Calculation results in Types $b, e$, and $h$.

\section{CONCLUSIONS}

The morphological features of a blowout formed on the sand dune on the Node coast were investigated in detail, and the topographic changes owing to windblown sand in the beach access extending from the land to the shoreline across the sand dune at Ishikari-hama Beach were observed. Furthermore, on the Node coast, time changes in the topography of the blowout and in shoreline position were investigated using aerial photographs. Owing to the analysis of the wind records in this area, the development of a blowout on the sand dune has begun since 2012, because the probability of strong wind with a velocity over $10 \mathrm{~m} / \mathrm{s}$ markedly increased since 2012 . This is the cause of the rapid development of a blowout. Finally, a model for predicting the formation of a blowout was developed using a cellular automaton method and numerical simulation was carried out given a small gap on the sand dune. The results of the numerical simulation were in good agreement with those measured on the Node coast. It was concluded that the beach access must be extended in the direction normal to the direction of prevailing wind to prevent blowout formation.

\section{REFERENCES}

Andreotti, B., P. Claudin, and S. Douady. 2002. Selection of dune shapes and velocities Part 1: Dynamics of sand, wind and barchans, Eur. Phys. J., B28, 321-339.

Katsuki, A., and M. Kikuchi. 2006. Simulation of barchan dynamics with interdune sand stream, RIMS Kokyuroku, 1472, 67-70. (in Japanese)

Katsuki, A., H. Nishimori, M. Kikuchi, N. Endo, and K. Taniguchi. 2011. Cellular model for sand dunes with saltation, avalanche and strong erosion: collisional simulation of barchans, Earth Surface Processes and Landforms, 36, 372-382.

NEDO: http://app8.infoc.nedo.go.jp/nedo/

Pye, K., and H. Tsoar. 1990. Aeolian Sand and Sand Dunes, Unwin Hyman, London, 42-43.

Yokota, T., A. Kobayashi, T. Uda, M. Serizawa, A. Katsuki, and Y. Noshi. 2017. Model for predicting formation of blowout on coastal sand dune using cellular automaton method, Proceedings of 9th International Conference on Asian and Pacific Coasts (APAC2017), 572-583. 